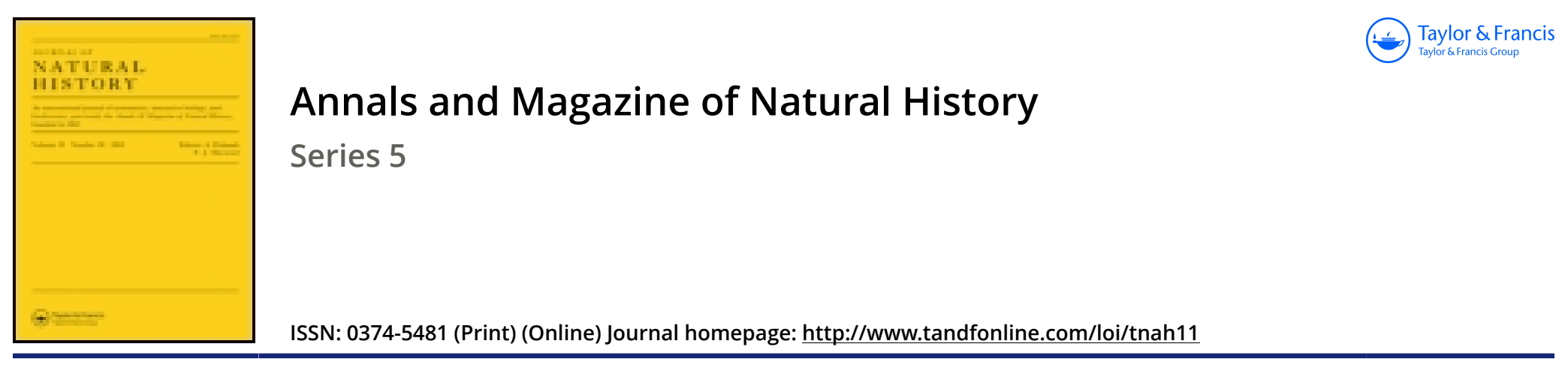

\title{
XXII.-On a small collection of lepidoptera from Western India and Beloochistan
}

\section{Arthur G. Butler F.L.S. F.Z.S.}

To cite this article: Arthur G. Butler F.L.S. F.Z.S. (1880) XXII._On a small collection of lepidoptera from Western India and Beloochistan , Annals and Magazine of Natural History, 5:27, 221-226, DOI: 10.1080/00222938009459414

To link to this article: http://dx.doi.org/10.1080/00222938009459414

$$
\text { Published online: } 07 \text { Oct } 2009 .
$$

\section{Submit your article to this journal $\square$}

Џ Article views: 2 
XXII.-On a small Collection of Lepidoptera from Western India and Beloochistan. By ÁrTuUr G. Butler, F.L.S., F.Z.S., \&c.

THE series of Lepidoptera of which the following is a list was obtained by Major Charles Swinhoe, for the most part from the Neilgherries and from Kurrachee*, but a few from Belgaum (Bombay Pres.), and three or four from Beloochistan.

With the exception of Pyrgus evanidus, the species from the last-mentioned locality do not differ from specimens previously obtained in North-western India.

\section{Nymphalidæ.}

$D_{\triangle N A I N A E}$.

1. Danais dorippus, Klug.

One example. Kurrachee; September 1879.

SATYRINE.

2. Hipparchia parisatis, Kollar.

Three examples. "Much," Bolan Pass, Beloochistan; August.

\section{NYMPHALINAE.}

3. Charaxes fabius, Fabricius.

One specimen. Neilgherries.

\section{ACREINA.}

4. Telchinia vesta, Fabricius.

One specimen. Neilgherries.

\section{Lycænidæ.}

\section{LYCXNINA.}

5. Anops phcedrus ơ, Fabricius.

One specimen. Belgaum (1879).

6. Lycoena Liarsandra, Moore.

Kurrachee, July.

Major Swinhoe sent thirty-three examples of this species

* Where Major Swinhoe is at present stationed. 
in a small pill-box; but unfortunately they were attacked by two specimens of a little beetle (Tribolium ferrugineum), which, by the time they arrived, had destroyed or damaged every specimen; only three retained the thorax intact so as to render it possible to set them out.

\section{Lycanesthes ubaldus, Cramer.}

Three specimens. Kurrachee, August.

\section{Papilionidæ.}

PIERIN

8. Teracolus protractus, Butler.

Two specimens. Hubb River, Beloochistan, August.

9. Teracolus puellaris, Butler.

One specimen $\left(\sigma^{\top}\right)$. Hubb River, Beloochistan; August. This prettly little species was evidently taken for a small example of the following, from which, however, it may readily be distinguished by the much broader black border of the secondaries. Mr. Moore received a long series of T. puellaris in a collection from Kutch (but T. vestalis did not come with it); it occurs also in the Punjab.

\section{Teracolus vestalis, Butler.}

Three specimens. Hubb River, Beloochistan and Kurrachee; August.

One male example is labelled "Muggin Peer." Is this Magar Pir, Kurrachee? The female is from Kurrachee.

The male of $T$. vestalis was described from a Scinde example, and the female from one taken at Agra, N.W. Punjab : the capture of it in Beloochistan therefore slightly extends its known range.

\section{Teracolus dirus, Butler.}

This species was described and figured from an albino female in Mr. Moore's collection; the ordinary form has the apical area of the primaries above broadly carmine, being, in fact, very similar to $T$. dulcis, but larger, the male with broader black internal border to the apical area; the basal area of the wings darker in both sexes, and with distinct blackish spots at the outer extremities of the first and second median branches on the under surface.

Four pairs. Kurrachee, July 1879.

Judging from an example of $T$. dulcis $q$ recently received 
from the India Museum, and which closely agrees in general characters (in the size of the marginal spots of secondaries, for instance, as well as in expanse) with the male which I figured, I have little doubt that the female figured by me is an ordinary $T$. dirus, and not T.dulcis at all ; it agrees well with Major Swinhoe's female specimens. Both species occur at Scinde.

\section{Belenois mesentina, Cramer.}

One pair. "Much," Bolan Pass, Beloochistan; October.

\section{Papilionine.}

13. Papilio doson, Felder.

One example, probably from the Neilgherries; locality not noted.

\section{Hesperiidæ.}

\section{Pyrgus evanidus, n. sp.}

Above extremely like $P$. galba, Fabr. ( $P$. superna, Moore), but distinctly greyer in colour, the ground-colour being black instead of brown; below greyer and paler, the secondaries being very faintly tinted with yellowish, the central white belt broken up into three spots, of which the two lower ones are contiguous, instead of forming one continuous band across the wings; other markings similar. Expanse of wings 11 lines.

Two specimens. Sao, Hubb River, Beloochistan; November.

\section{Plesioneura ambareesa, Moore.}

One male. Matheran.

\section{Chalcosiidæ.}

16. Chalcosia affinis, Guérin.

Two specimens from Belgaum, and two from the Neilgherries.

\section{Lithosiidæ.}

HYPSINAE.

17. Damalis strigivenata, Butler.

Belgaum.

\section{Ennomidæ.}

18. Hyperythra Swinhoei, n. sp.

Above ochreous buff, minutely and sparsely speckled with 


\section{Mr. A. G. Butler on a Collection of Lepidoptera}

brown; primaries with traces of two parallel slightly arched discal brown lines, the outer one limited externally by two diffused brown patches, the larger one extending from costa to lower radial, the lower one on second median interspace; a minute indistinct brown discocellular spot: secondaries with traces of two closely approximated blackish abbreviated discal lines from costa to second median branch, the outer line interrupted near costa by two large rounded blackish spots: body yellow, sericeous. Wings below bright yellow, sparsely sprinkled with fine abbreviated purplish-brown striæ; external area tinted with saffron-yellow and limited internally by a slightly sinuated purplish-brown line; discocellular dots and an ill.defined line just beyond the cell of secondaries purplish brown: body below bright yellow in the centre, tinted with saffron-yellow at the sides. Expanse of wings 1 inch 4 lines.

One male. Kurrachee, October 1879.

\section{Geometridæ.}

19. Nemoria pruinosa, n. sp.

Sea-green, densely irrorated with silvery white; body pale yellow, antennæ testaceous. Wings below silvery white, slightly tinted in front with green; body below creamcoloured. Expanse of wings $7 \frac{1}{2}$ lines.

One male. Kurrachee, September 1879.

\section{Macariidæ.}

20. Tephrina strenuataria.

Macaria strenuataria, Walker.

Three examples. Kurrachee, May and September.

Noctuidæ.

21. Graphiphora c-nigrum.

Phalana-Noctua c-nigrum, Linn.

'Two specimens. Neilgherries.

\section{Orthosiidæ.}

22. Orthosia erubescens, n. sp.

Primaries above shining pinky brown; base crossed by small black dots; discoidal spots imperfectly represented by interrupted black outlines; discal lines barely indicated by indistinct greyish curved stripes ; costa towards apex suffused with blackish : secondaries pale sericeous greyish brown, 
slightly cupreous upon the margin, fringe whitish at base: thorax pinky brown, vertex of head and front of palpi white; abdomen greyish brown, with testaceous lateral and anal tufts. Wings below shining chalky white, with pinky-brownish costal borders ; discocellular stigma and an abbreviated discal line grey; primaries with the discoidal area greyish: body below testaceous, washed at the sides with dull reddish. Expanse of wings 1 inch 3 lines.

One male. Neilgherries.

\section{Hadenidæ.}

23. Euplexia albovittata, Moore.

One specimen. Neilgherries.

Ommatophoridæ.

24. Nyctipao letitia, Butler.

One example. Belgaum, 1879.

\section{Ophiusidæ.}

25. Grammodes stulida, Fabr.

'Two specimens. Kurrachee, July and October.

Remigiidæ.

26. Remigia frugalis, Fabr.

'Three specimens. Kurrachee, October.

\section{Thermesiidæ.}

27. Azazia rubricans, Boisd.

Four examples. Kurrachee, October.

One specimen is considerably darker than the three others.

\section{Hypenidæ.}

28. Iypena laceratalis, Walker.

Mulleer near Kurrachee, November.

\section{Docela affinis, n. sp.}

Closely allied to $D$. vetustalis, from which it principally differs in the darker central band of primaries and the broader yellow band of secondaries: grey; wings crossed by an irregular blackish band, interrupted upon the secondaries, which it traverses at basal third, angulated and central upon primaries; 
a yellow discal band with blackish external margin, very slender upon primaries, but widened into an elongated triangular patch upon the secondaries, bounded outwardly upon the primaries by three dark brown spots and towards apex of secondaries by a large dark brown patch; external border bronzy, fringe varied with white ; primaries with a small redbrown reniform spot with pale border. Under surface sordid white; wings with blackish apical patches, fringe snow-white at apex. Expanse of wings 11 lines.

One example. Kurrachee, October.

There are also two specimens in Mr. Moore's collection. This genus much resembles in marking the Noctuid group Microphysa, but differs in its much longer and thicker palpi.

\section{Asopiidæ.}

30. Hymenia fascialis, Cramer.

Three specimens. Kurrachee, June and October.

\section{Botydidæ.}

31. Botys iopasalis, Walker.

Three specimens. Kurrachee, September and October.

32. Godara comalis, Guénée.

Two specimens. Kurrachee, October.

\section{Tineidæ.}

33. Alavona barbarella?, Walker.

Matheran, May 1879.

I cannot be perfectly certain of the identification of this species, owing to the rubbed condition of the type and the difficulty of tracing the markings in any but very good specimens of this genus.

XXIII.-On a Collection of Crustacea from the Malaysian Region.-Part I. Crustacea Oxyr'yncha and Cyclometopa, except Telphusidea. By EDward J. Miers, F.L.S., F.T.S.

[Plate XIII.]

THE present paper, which will be continued in succeeding numbers of the 'Annals,' will contain a complete enumeration, with notes and descriptions (where needed), of the Crus- 